\title{
PENERAPAN MODEL TRANSPORTASI DAN DECISION TREE PADA DISTRIBUSI BARANG
}

\author{
Arlita Armanto; Haryadi Sarjono \\ Management Department, School of Business Management, Binus University, \\ Jl. K. H. Syahdan No. 9, Palmerah, Jakarta Barat 11480, Indonesia
}

\begin{abstract}
Goods distribution has a firm connection with transportation cost. Transportation method used by a company will cause great impact on company's profit. If company's profit can be maximal, the company will be able to develop its business even greater. Some problem solution steps proposed were: determining optimum criteria, developing alternative solution, developing optimum model, and practicing chosen implicative planning solution. These steps were implemented to obtain optimum goods distribution cost to gain maximum profit. This research resulted in that the distribution cost for goods implemented by current method in the company has been already optimum. Then for the following development, Decision Tree Method was used, where the results are: shipping to Yogyakarta using Sinar Aji transportation service with minimum EMV Rp.2.993.342; shipping to Salatiga using own car with EMV Rp.2.659.388; shipping to Purwokerto using Sinar Aji transportation service with EMV Rp.2.563.859; shipping to Cirebon using Sinar Aji transportaion service with EMV Rp.2.443.792; shipping to Semarang using Sinar Aji transportation service with EMV Rp.4.203.489. As the conclusion, goods shipping method which has been implemented by the company until now is optimum so it still can be used for any following business development as well as provides an iluustrative plan for the company.
\end{abstract}

Keywords: transportation method, decision tree, efficiency, shipping, distribution

\begin{abstract}
ABSTRAK
Pendistribusian barang sangat erat kaitannya dengan biaya Transportasi. Metode Transportasi yang digunakan oleh perusahaan akan berdampak besar pada profit perusahaan tersebut. Apabila profit yang diperoleh perusahaan dapat maksimal, perusahaan akan mampu mengembangkan usahanya menjadi lebih besar lagi. Langkah pemecahan masalah yang dilakukan yaitu penetapan kriteria optimasi, pengembangan alternatif solusi, pengembangan model optimasi, serta melakukan rancangan implikasi solusi terpilih. Langkah-langkah ini digunakan untuk mengoptimalkan biaya pengiriman barang untuk memperoleh profit yang maksimal. Penelitian memperoleh hasil yaitu biaya pengiriman barang menggunakan metode yang sedang berjalan di perusahaan sudah optimal. Untuk pengembangan usaha selanjutnya, digunakan metode Decision Tree diperoleh hasil pengiriman barang ke kota Yogyakarta menggunakan jasa angkutan Sinar Aji dengan EMV paling kecil yaitu Rp.2.993.342, pengiriman barang ke kota Salatiga menggunakan mobil sendiri dengan EMV Rp.2.659.388, pengiriman barang ke kota Purwokerto menggunakan jasa angkutan Sinar Aji dengan EMV Rp.2.563.859, pengiriman barang ke kota Cirebon menggunakan jasa angkutan Sinar Aji dengan EMV Rp.2.443.792, pengiriman barang ke kota Semarang menggunakan jasa angkutan Sinar Aji dengan EMV Rp.4.203.489. Dapat disimpulkan bahwa metode pengiriman barang yang telah dilakukan perusahaan selama ini sudah optimal sehingga dapat terus digunakan untuk pengembangan usaha selanjutnya, serta memberikan gambaran yang sebaiknya dilakukan oleh perusahaan.
\end{abstract}

Kata kunci: transportation method, decision tree, efisiensi, pengiriman, distribusi 


\section{PENDAHULUAN}

Persaingan antar perusahaan distribusi sangat ketat, baik dari faktor permodalan, kelengkapan jenis produk yang dijual, jaringan pelanggan yang dimiliki oleh perusahaan, harga jual, pemberian service ke pelanggan yang berupa keramahan SDM yang menerima order, kecepatan dan ketelitian proses order yang masuk, hingga pengiriman pesanan sampai ke pelanggan. Memberi pelayanan yang terbaik kepada pelanggan sehingga pelanggan puas merupakan tujuan utama setiap perusahaan distribusi. Sedangkan untuk mencapai tujuan tersebut perusahaan harus mempertimbangkan banyak faktor. Permasalahan utama yang sedang dihadapi oleh PT. Suryamas Inti Armindo yaitu biaya distribusi barang yang semakin mahal dikarenakan kondisi ekonomi negara yang tidak stabil serta harga bahan bakar minyak yang terus meningkat membuat biaya transportasi yang dikeluarkan oleh perusahaan juga semakin besar.

Perlu diperhitungkan biaya-biaya dari data di atas dimana untuk tujuan yang ingin dicapai dalam penelitian ini, yaitu: (1) untuk mengetahui biaya optimal pengiriman barang PT.Suryamas Inti Armindo dengan menggunakan jasa angkutan paket menurut metode transportasi. (2) untuk mengetahui metode yang sebaiknya digunakan oleh PT.Sinarmas Inti Armindo. (3) untuk mendapatkan alternatif solusi yang sebaiknya dipilih oleh PT.Suryamas Inti Armindo dalam mengoptimalkan efisiensi biaya pengiriman barang untuk masing-maing kota tujuan melalui pendekatan Decision Tree.

\section{METODE}

Jenis penelitian yang digunakan adalah penelitian kuantitatif. Penelitian pengujian yang digunakan adalah analisis kuantitatif bisnis. Metode pengumpulan data yang dilakukan dengan studi pustaka dengan mengumpulkan data sekunder baik data yang dimiliki oleh perusahaan, jurnal atau sumber-sumber lainnya dan field research data yang diperoleh dengan hasil wawancara terhadap pemimpin perusahaan. Dalam perhitungan biaya yang optimal digunakan metode transportasi dengan dibantu software QM for Windows 2. Dalam penggunaan software tersebut terdapat tiga metode transportasi yaitu metode Northwest Corner (NWC), metode Least Cost, dan metode VAM sebagai solusi awal dan metode Stepping Stone dan MODI sebagai solusi akhir.

\section{HASIL DAN PEMBAHASAN}

Perhitungan dilakukan berdasarkan data biaya angkutan menggunakan jasa paket. Adapun kapasitas setiap angkutan paket masing-masing: 9.800, 9.600, 9.400, 8.500, 7.500 kg, sedangkan permintaan dari setiap pelanggannya masing-masing: 7.898, 9.619, 4.832, 4.960, $11.091 \mathrm{~kg}$ (Tabel 1).

Tabel 1 Tabel Biaya Transportasi Beserta Kapasitas dan Permintaan

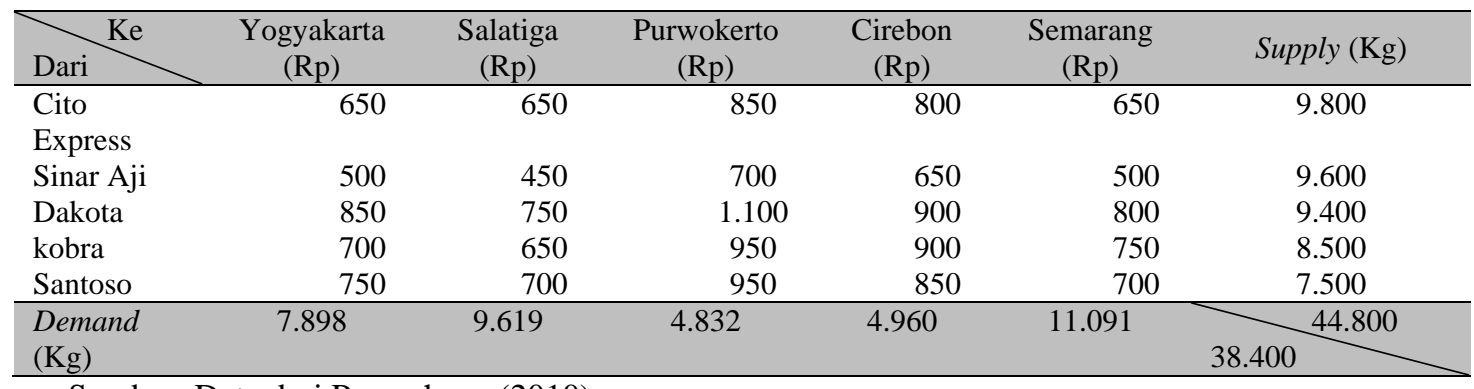

Sumber: Data dari Perusahaan (2010) 


\section{Metode NWC}

Berikut adalah perincian untuk biaya per angkutan untuk hasil metode NWC:

Daerah Yogyakarta mendapatkan supply dari dua angkutan. Masing-masing adalah supply dari Cito Express sebesar 6.209 kg, dan dari Sinar Aji sebesar $1.689 \mathrm{~kg}$. Biaya dari Cito Express adalah sebesar Rp 650,-/kg sedangkan biaya dari Sinar Aji adalah sebesar Rp 500,-/kg. Maka biaya yang dibebankan untuk daerah Yogyakarta adalah sebesar Rp 4.880.350,-. Perinciannya adalah jumlah barang dikalikan dengan biaya per $\mathrm{kg}$ barang [(6.209 x Rp 650,-) + $(1.689 \times \mathrm{Rp} 500,-)=\mathrm{Rp}$ 4.880.350,-]

Daerah Salatiga mendapatkan supply dari 2 angkutan. Masing-masing adalah supply dari Sinar Aji sebesar $1.119 \mathrm{~kg}$, dan dari Kobra sebesar $8.500 \mathrm{~kg}$. Biaya dari Sinar Aji adalah sebesar Rp 450,-/kg sedangkan biaya dari Kobra adalah sebesar Rp 650,-/kg. Maka biaya yang dibebankan untuk daerah Salatiga adalah sebesar Rp 6.028.550,-. Perinciannya adalah jumlah barang dikalikan dengan biaya per kg barang [(1.119 x Rp 450,-) + (8.500 x Rp 650,-) $=$ Rp 6.028.550,-]

Daerah Purwokerto dikirim oleh Sinar Aji dengan jumlah barang yang disupply sebesar $4.832 \mathrm{~kg}$ dengan biaya sebesar Rp 700/kg. Maka jumlah biaya yang dibebankan untuk daerah Purwokerto adalah sebesar Rp 3.382.400,-. Jumlah tersebut didapatkan dari perkalian jumlah barang dengan biaya per kg barang (4.832 x Rp 700/kg = Rp 3.382.400,-)

Daerah Cirebon mendapatkan supply dari 2 angkutan. Masing-masing adalah supply dari Sinar Aji sebesar $1.960 \mathrm{~kg}$, dan dari Dakota sebesar $3.000 \mathrm{~kg}$. Biaya dari Sinar Aji adalah sebesar Rp 650,-/kg sedangkan biaya dari Dakota adalah sebesar Rp 900,-/kg. Maka biaya yang dibebankan untuk daerah Cirebon adalah sebesar Rp 3.974.000,-. Perinciannya adalah jumlah barang dikalikan dengan biaya per kg barang [(1.960 x Rp 650,-) + (3.000 x Rp 900,-) $=$ Rp 3.974.000,-]

Daerah Semarang mendapatkan supply dari 2 angkutan. Masing-masing adalah supply dari Cito Express sebesar $3.591 \mathrm{~kg}$, dan dari Santoso sebesar $7.500 \mathrm{~kg}$. Biaya dari Cito Express adalah sebesar Rp 650,-/kg sedangkan biaya dari Santoso adalah sebesar Rp 700,-/kg. Maka biaya yang dibebankan untuk daerah Semarang adalah sebesar Rp 7.584.150,-. Perinciannya adalah jumlah barang dikalikan dengan biaya per kg barang [(3.591 x Rp 650,-) + (7.500 x Rp 700,-) = Rp 7.584.150,-]

Untuk sisa barang dari supply yang tidak terpakai dialokasikan ke dalam dummy. Dummy tersebut tidak memiliki biaya pengiriman.

\section{Metode Least Cost}

Berikut adalah perincian untuk biaya per angkutan untuk metode Least Cost:

Daerah Yogyakarta dikirim oleh Kobra dengan jumlah barang yang disupply sebesar 7.898 kg dengan biaya sebesar Rp 700/kg. Maka jumlah biaya yang dibebankan untuk daerah Yogyakarta adalah sebesar Rp 5.528.600,-. Jumlah tersebut didapatkan dari perkalian jumlah barang dengan biaya per kg barang (7.898 x Rp 700/kg = Rp 5.528.600,-)

Daerah Salatiga mendapatkan supply dari 2 angkutan. Masing-masing adalah supply dari Sinar Aji sebesar 9.017 kg, dan dari Kobra sebesar 602 kg. Biaya dari Sinar Aji adalah sebesar Rp 450,-/kg sedangkan biaya dari Kobra adalah sebesar Rp 650,-/kg. Maka biaya yang dibebankan untuk daerah Salatiga adalah sebesar Rp 4.448.950,-. Perinciannya adalah jumlah barang dikalikan dengan biaya per kg barang [(9.017 x Rp 450,-) + (602 x Rp 650,-) = Rp 4.448.950,-] 
Daerah Purwokerto mendapatkan supply dari 2 angkutan. Masing-masing adalah supply dari Cito Express sebesar $4.249 \mathrm{~kg}$, dan dari Sinar Aji sebesar $583 \mathrm{~kg}$. Biaya dari Cito Express adalah sebesar Rp 850,-/kg sedangkan biaya dari Sinar Aji adalah sebesar Rp 700,-/kg. Maka biaya yang dibebankan untuk daerah Purwokerto adalah sebesar Rp 4.019.750,-. Perinciannya adalah jumlah barang dikalikan dengan biaya per kg barang [(4.249 x Rp 850,-) + (583 x Rp 700,-) = Rp 4.019.750,-]

Daerah Cirebon mendapatkan supply dari 2 angkutan. Masing-masing adalah supply dari Cito Express sebesar $1.960 \mathrm{~kg}$, dan dari Dakota sebesar $3.000 \mathrm{~kg}$. Biaya dari Cito Express adalah sebesar Rp 800,-/kg sedangkan biaya dari Dakota adalah sebesar Rp 900,-/kg. Maka biaya yang dibebankan untuk daerah Cirebon adalah sebesar Rp 4.268.000,-. Perinciannya adalah jumlah barang dikalikan dengan biaya per kg barang [(1.960 x Rp 800,-) + (3.000 x Rp 900,-) = Rp 4.268.000,-]

Daerah Semarang mendapatkan supply dari 2 angkutan. Masing-masing adalah supply dari Cito Express sebesar $3.591 \mathrm{~kg}$, dan dari Santoso sebesar $7.500 \mathrm{~kg}$. Biaya dari Cito Express adalah sebesar Rp 650,-/kg sedangkan biaya dari Santoso adalah sebesar Rp 700,-/kg. Maka biaya yang dibebankan untuk daerah Semarang adalah sebesar Rp 7.584.150,-. Perinciannya adalah jumlah barang dikalikan dengan biaya per kg barang [(3.591 x Rp 650,-) + (7.500 x Rp 700,-) = Rp 7.584.150,-]

Untuk sisa barang dari supply yang tidak terpakai dialokasikan ke dalam dummy. Dummy tersebut tidak memiliki biaya pengiriman.

\section{Metode VAM}

Berikut adalah perincian untuk biaya per angkutan untuk metode VAM:

Daerah Yogyakarta dikirim oleh Kobra dengan jumlah barang yang disupply sebesar 7.898 kg dengan biaya sebesar Rp 700/kg. Maka jumlah biaya yang dibebankan untuk daerah Yogyakarta adalah sebesar Rp 5.528.600,-. Jumlah tersebut didapatkan dari perkalian jumlah barang dengan biaya per kg barang (7.898 x Rp 700/kg = Rp 5.528.600,-)

Daerah Salatiga mendapatkan supply dari 2 angkutan. Masing-masing adalah supply dari Sinar Aji sebesar 9.017 kg, dan dari Kobra sebesar 602 kg. Biaya dari Sinar Aji adalah sebesar Rp 450,-/kg sedangkan biaya dari Kobra adalah sebesar Rp 650,-/kg. Maka biaya yang dibebankan untuk daerah Salatiga adalah sebesar Rp 4.448.950,-. Perinciannya adalah jumlah barang dikalikan dengan biaya per kg barang [(9.017 x Rp 450,-) + (602 x Rp 650,-) = Rp 4.448.950,-]

Daerah Purwokerto mendapatkan supply dari 2 angkutan. Masing-masing adalah supply dari Cito Express sebesar $4.249 \mathrm{~kg}$, dan dari Sinar Aji sebesar $583 \mathrm{~kg}$. Biaya dari Cito Express adalah sebesar Rp 850,-/kg sedangkan biaya dari Sinar Aji adalah sebesar Rp 700,-/kg. Maka biaya yang dibebankan untuk daerah Purwokerto adalah sebesar Rp 4.019.750,-. Perinciannya adalah jumlah barang dikalikan dengan biaya per kg barang [(4.249 x Rp 850,-) + (583 x Rp 700,-) = Rp 4.019.750,-]

Daerah Cirebon mendapatkan supply dari 2 angkutan. Masing-masing adalah supply dari Dakota sebesar $3.000 \mathrm{~kg}$, dan dari Santoso sebesar $1.960 \mathrm{~kg}$. Biaya dari Dakota adalah sebesar Rp 900,-/kg sedangkan biaya dari Santoso adalah sebesar Rp 850,-/kg. Maka biaya yang dibebankan untuk daerah Cirebon adalah sebesar Rp 4.366.000,-. Perinciannya adalah jumlah barang dikalikan dengan biaya per kg barang [(3.000 x Rp 900,-) + (1.960 x Rp 850,-) $=$ Rp 4.366.000,-]

Daerah Semarang mendapatkan supply dari 2 angkutan. Masing-masing adalah supply dari Cito Express sebesar $5.551 \mathrm{~kg}$, dan dari Santoso sebesar $5.540 \mathrm{~kg}$. Biaya dari Cito Express adalah sebesar Rp 650,-/kg sedangkan biaya dari Santoso adalah sebesar Rp 700,-/kg. Maka biaya yang 
dibebankan untuk daerah Semarang adalah sebesar Rp 7.486.150,-. Perinciannya adalah jumlah barang dikalikan dengan biaya per kg barang [(5.551 x Rp 650,-) + (5.540 x Rp 700,-) = Rp 7.486.150,-]

Untuk sisa barang dari supply yang tidak terpakai dialokasikan ke dalam dummy. Dummy tersebut tidak memiliki biaya pengiriman.

Ketiga hasil di atas dirangkum dan dibandingkan dalam Tabel 2.

Tabel 2 Perbandingan Hasil Metode Transportasi (dalam rupiah)

\begin{tabular}{ccccc}
\hline Nama Daerah & Metode Sedang Berjalan & Metode NWC & Metode Least Cost & Metode VAM \\
\hline Yogyakarta & 4.803 .283 & 4.880 .350 & 5.528 .600 & 5.528 .600 \\
Salatiga & 3.969 .236 & 6.028 .550 & 4.448 .950 & 4.448 .950 \\
Purwokerto & 4.585 .539 & 3.382 .400 & 4.019 .750 & 4.019 .750 \\
Cirebon & 4.579 .247 & 3.974 .000 & 4.268 .000 & 4.366 .000 \\
Semarang & 6.777 .887 & 7.584 .150 & 7.584 .150 & 7.486 .150 \\
\hline Total & $\mathbf{2 4 . 7 1 5 . 1 9 2}$ & $\mathbf{2 5 . 8 4 9 . 4 5 0}$ & $\mathbf{2 5 . 8 4 9 . 4 5 0}$ & $\mathbf{2 5 . 8 4 9 . 4 5 0}$ \\
\hline
\end{tabular}

Sumber: Hasil Pengolahan Data (2010)

Setelah mengetahui hasil perhitungan biaya pengiriman dengan metode permodelan transportasi yang dibantu dengan software QM for Windows 2, didapatkan hasil sebesar Rp 25.849.450,- untuk perhitungan biaya transportasi dengan model optimasi dan Rp 24.715.192,- untuk perhitungan biaya dengan metode yang sedang berjalan. Dengan demikian biaya pengiriman barang yang dilakukan oleh perusahaan sekarang sudah optimal.

Setelah itu,dilanjutkan dengan Decision Tree model untuk menentukan metode pengiriman terbaik pada masing-masing kota tujuan (Tabel 3 - 7).

\section{Decision Tree Model}

Tabel 3 Data Peluang dan Nilai Hasil Keputusan untuk Decision Tree Kota Yogyakarta

\begin{tabular}{llcccc}
\hline \multirow{2}{*}{ No } & Keterangan & \multicolumn{2}{c}{ Peluang Bagi Kondisi Alamiah } & \multicolumn{2}{c}{ Nilai Hasil Keputusan (Rp) } \\
\cline { 3 - 5 } & & Ekonomi Baik & Ekonomi Buruk & Ekonomi Baik & Ekonomi Buruk \\
\hline & & 0,7 & 0,3 & 4.803 .283 & $(480.328)$ \\
\hline 1. & Mobil Sendiri & & & & \\
& & 0,75 & 0,25 & 5.133 .700 & $(513.370)$ \\
1. & Cito Express & 0,78 & 0,22 & 3.949 .000 & $(394.900)$ \\
2. & Sinar Aji & 0,77 & 0,23 & 6.713 .300 & $(671.330)$ \\
3. & Dakota & 0,79 & 0,21 & 5.528 .600 & $(552.860)$ \\
4. & Kobra & 0,71 & 0,29 & 5.923 .500 & $(592.350)$ \\
5. & Santoso & & & & \\
\hline
\end{tabular}

Sumber: Data dari Perusahaan (2010)

Ekonomi buruk didapat dengan asumsi terjadi kenaikan biaya sebesar $10 \%$ dari harga ekonomi baik.

Untuk Pengiriman dengan angkutan sendiri:

$$
\begin{aligned}
\text { EMV (mobil sendiri) } & =(0,7)(\mathrm{Rp} 4.803 .283)+(0,3)(-\mathrm{Rp} 480.328) \\
& =\operatorname{Rp} 3.362 .298-\operatorname{Rp} 144.098 \\
& =\operatorname{Rp} 3.218 .200
\end{aligned}
$$


Untuk Pengiriman dengan jasa angkutan paket:

\begin{tabular}{|c|c|}
\hline EMV (Cito Express) & $\begin{array}{l}=(0,75)(\operatorname{Rp} 5.133 .700)+(0,25)(-\operatorname{Rp} 513.370) \\
=\operatorname{Rp} 3 \cdot 850.275-\operatorname{Rp} 128.343 \\
=\operatorname{Rp} 3 \cdot 721.932\end{array}$ \\
\hline EMV (Sinar Aji) & $\begin{array}{l}=(0,78)(\mathrm{Rp} 3.949 .000)+(0,22)(-\mathrm{Rp} 394.900) \\
=\mathrm{Rp} 3.080 .220-\mathrm{Rp} 86.878 \\
=\mathrm{Rp} 2 \cdot 993.342\end{array}$ \\
\hline EMV (Dakota) & $\begin{array}{l}=(0,77)(\operatorname{Rp} 6.713 .300)+(0,23)(-\operatorname{Rp} 671.330) \\
=\operatorname{Rp~5.169.241-Rp~154.406~} \\
=\operatorname{Rp} 5.014 .835\end{array}$ \\
\hline EMV (Kobra) & $\begin{array}{l}=(0,79)(\mathrm{Rp} 5.528 .600)+(0,21)(-\mathrm{Rp} 552.860) \\
=\operatorname{Rp} 4.367 .594-\mathrm{Rp} 116.100 \\
=\operatorname{Rp} 4.251 .494\end{array}$ \\
\hline EMV (Santoso) & $\begin{array}{l}=(0,71)(\operatorname{Rp} 5.923 .500)+(0,29)(-\operatorname{Rp} 592.350) \\
=\operatorname{Rp} 4.205 .685-\operatorname{Rp} 171.782 \\
=\text { Rp 4.033.903 }\end{array}$ \\
\hline
\end{tabular}

Nilai EMV yang digunakan dalam mengisi noda keputusan setelah noda cabang adalah: untuk Angkutan Sendiri menggunakan EMV mobil sendiri, yaitu sebesar Rp 3.218.200,-. Sedangkan untuk Jasa Angkutan Paket menggunakan EMV Sinar Aji, yang bernilai paling rendah jika dibandingkan dengan EMV Cito Express, EMV Dakota, EMV Kobra, dan EMV Santoso; yaitu dengan EMV Sinar Aji sebesar Rp 2.993.342,--.

Langkah terakhir dalam menentukan titik keputusan yang dapat diambil oleh perusahaan adalah dengan memilih cabang dari hasil EMV terendah yang sebelumnya telah diperoleh untuk jasa angkutan paket dan angkutan sendiri. Pilihan keputusan jatuh pada jasa angkutan paket Sinar Aji, karena memberikan nilai harapan moneter terendah (EMV terendah) (Gambar 1).

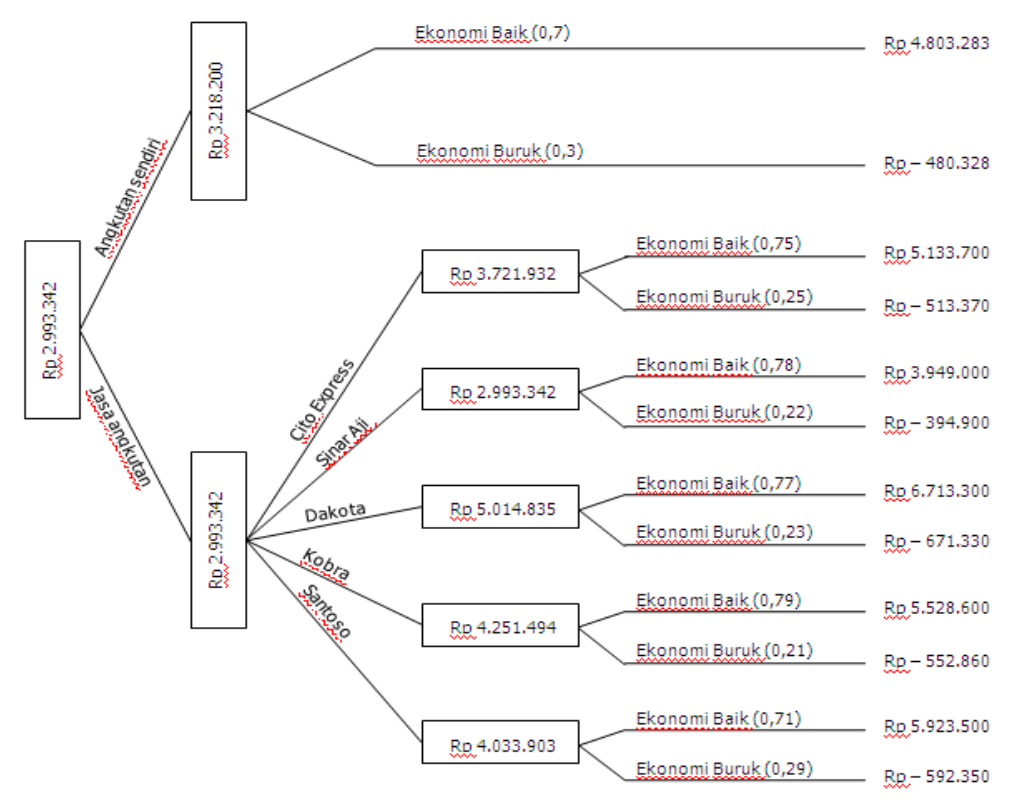

Gambar 1. Diagram pohon untuk menentukan metode pengiriman terbaik kota Tujuan Yogyakarta (Sumber: Hasil pengolahan data, 2010). 
Tabel 4 Data Peluang dan Nilai Hasil Keputusan untuk Decision Tree Kota Salatiga

\begin{tabular}{llcccc}
\hline \multirow{2}{*}{ No } & \multicolumn{1}{c}{ Keterangan } & \multicolumn{2}{c}{ Peluang Bagi Kondisi Alamiah } & \multicolumn{2}{c}{ Nilai Hasil Keputusan (Rp) } \\
\cline { 3 - 5 } & & Ekonomi Baik & Ekonomi Buruk & Ekonomi Baik & Ekonomi Buruk \\
\hline \multirow{2}{*}{ 1. } & Mobil Sendiri & 0,7 & 0,3 & 3.969 .236 & $(396.923)$ \\
& & & & & \\
1. & Cito Express & 0,75 & 0,25 & 6.252 .350 & $(625.235)$ \\
2. & Sinar Aji & 0,78 & 0,22 & 4.328 .550 & $(432.855)$ \\
3. & Dakota & 0,77 & 0,23 & 7.214 .250 & $(721.425)$ \\
4. & Kobra & 0,79 & 0,21 & 6.252 .350 & $(625.235)$ \\
5. & Santoso & 0,71 & 0,29 & 6.733 .300 & $(673.330)$ \\
\hline \multicolumn{2}{r}{ Sumber: Data dari Perusahaan (2010) }
\end{tabular}

Ekonomi buruk didapat dengan asumsi terjadi kenaikan biaya sebesar 10\% dari harga ekonomi baik.

Untuk pengiriman dengan angkutan sendiri:

$$
\begin{aligned}
\text { EMV (mobil sendiri) } & =(0,7)(\mathrm{Rp} 3.969 .236)+(0,3)(-\mathrm{Rp} 396.923) \\
& =\mathrm{Rp} 2.778 .465-\mathrm{Rp} 119.077 \\
& =\mathrm{Rp} 2.659 .388
\end{aligned}
$$

Untuk pengiriman dengan jasa angkutan paket:

$$
\begin{aligned}
& \text { EMV (Cito Express) } \quad=(0,75)(\mathrm{Rp} 6.252 .350)+(0,25)(-\mathrm{Rp} 625.235) \\
& =\mathrm{Rp} 4.689 .263-\mathrm{Rp} 156.309 \\
& =\operatorname{Rp} 4.532 .954 \\
& \operatorname{EMV}(\text { Sinar Aji }) \quad=(0,78)(\mathrm{Rp} 4.328 .550)+(0,22)(-\mathrm{Rp} 432.855) \\
& =\operatorname{Rp} 3.376 .269-\mathrm{Rp} 95.228 \\
& =\mathrm{Rp} 3.281 .041 \\
& \operatorname{EMV~(Dakota)~} \quad=(0,77)(\mathrm{Rp} 7.214 .250)+(0,23)(-\mathrm{Rp} 721.425) \\
& =\operatorname{Rp} 5.554 .973-\mathrm{Rp} 165.928 \\
& =\operatorname{Rp} 5.389 .045 \\
& \text { EMV (Kobra) } \quad=(0,79)(\operatorname{Rp} 6.252 .350)+(0,21)(- \text { Rp 625.235) } \\
& =\mathrm{Rp} \text { 4.939.357 }-\mathrm{Rp} 131.299 \\
& =\operatorname{Rp} 4.808 .058 \\
& \text { EMV (Santoso) } \quad=(0,71)(\mathrm{Rp} \mathrm{6.733.300)}+(0,29)(-\mathrm{Rp} 673.330) \\
& =\mathrm{Rp} 4.780 .643-\mathrm{Rp} 195.266 \\
& =\operatorname{Rp} 4.585 .377
\end{aligned}
$$

Nilai EMV yang digunakan dalam mengisi noda keputusan setelah noda cabang adalah: untuk Angkutan Sendiri menggunakan EMV mobil sendiri, yaitu sebesar Rp 2.659.388,-. Sedangkan untuk Jasa Angkutan Paket menggunakan EMV Sinar Aji, yang bernilai paling rendah jika dibandingkan dengan EMV Cito Express, EMV Dakota, EMV Kobra, dan EMV Santoso; yaitu dengan EMV Sinar Aji sebesar Rp 3.281.041,-.

Langkah terakhir dalam menentukan titik keputusan yang dapat diambil oleh perusahaan adalah dengan memilih cabang dari hasil EMV terendah yang sebelumnya telah diperoleh untuk jasa angkutan paket dan angkutan sendiri. Pilihan keputusan jatuh pada angkutan mobil sendiri, karena memberikan nilai harapan moneter terendah (EMV terendah) (Gambar 2). 


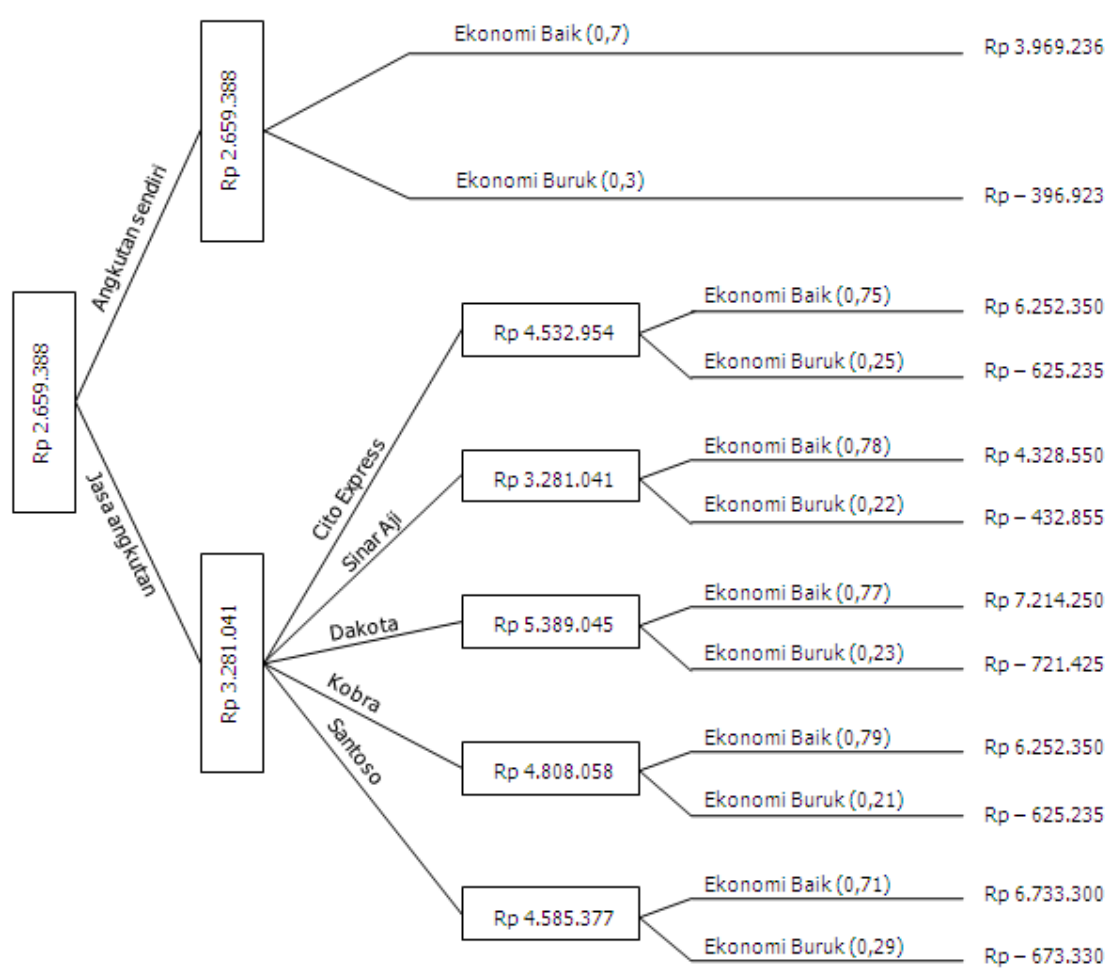

Gambar 2. Diagram pohon untuk menentukan metode pengiriman terbaik tujuan kota Salatiga (Sumber: Hasil pengolahan data, 2010).

Tabel 5 Data Peluang dan Nilai Hasil Keputusan untuk Decision Tree Kota Purwokerto

\begin{tabular}{clcccc}
\hline \multirow{2}{*}{ No } & Keterangan & \multicolumn{2}{c}{ Peluang Bagi Kondisi Alamiah } & \multicolumn{2}{c}{ Nilai Hasil Keputusan (Rp) } \\
\cline { 3 - 6 } & Ekonomi Baik & Ekonomi Buruk & Ekonomi Baik & Ekonomi Buruk \\
\hline \multirow{2}{*}{ 1. } & Mobil Sendiri & 0,7 & 0,3 & 4.585 .539 & $(458.554)$ \\
& & & & \\
1. & Cito Express & 0,75 & 0,25 & 4.107 .200 & $(410.720)$ \\
2. & Sinar Aji & 0,78 & 0,22 & 3.382 .400 & $(338.240)$ \\
3. & Dakota & 0,77 & 0,23 & 5.315 .200 & $(531.520)$ \\
4. & Kobra & 0,79 & 0,21 & 4.590 .400 & $(459.040)$ \\
5. & Santoso & 0,71 & 0,29 & 4.590 .400 & $(459.040)$ \\
\hline \multicolumn{5}{r}{ Sumber: Data dari Perusahaan (2010) }
\end{tabular}

Ekonomi buruk didapat dengan asumsi terjadi kenaikan biaya sebesar $10 \%$ dari harga ekonomi baik.

Untuk pengiriman dengan angkutan sendiri:

EMV (mobil sendiri) $\quad=(0,7)(\mathrm{Rp} 4.585 .539)+(0,3)(-\mathrm{Rp} 458.554)$

$$
\begin{aligned}
& =\text { Rp 3.209.877-Rp 137.566 } \\
& =\text { Rp 3.072.311 }
\end{aligned}
$$

Untuk pengiriman dengan jasa angkutan paket:

$$
\begin{aligned}
\text { EMV (Cito Express) } & =(0,75)(\operatorname{Rp} 4.107 .200)+(0,25)(- \text { Rp 410.720) } \\
& =\operatorname{Rp} 3.080 .400-\operatorname{Rp} 102.680 \\
& =\operatorname{Rp} 2.977 .720
\end{aligned}
$$




$$
\begin{aligned}
& \text { EMV }(\text { Sinar Aji }) \quad=(0,78)(\mathrm{Rp} 3.382 .400)+(0,22)(-\mathrm{Rp} 338.240) \\
& =\mathrm{Rp} 2.638 .272-\mathrm{Rp} 74.413 \\
& =\mathrm{Rp} 2.563 .859 \\
& \text { EMV (Dakota) } \quad=(0,77)(\operatorname{Rp} 5.315 .200)+(0,23)(- \text { Rp 531.520) } \\
& =\operatorname{Rp} 4.092 .704-\mathrm{Rp} 122.250 \\
& =\operatorname{Rp} 3.970 .454 \\
& \operatorname{EMV~(Kobra)~} \quad=(0,79)(\mathrm{Rp} 4.590 .400)+(0,21)(-\mathrm{Rp} 459.040) \\
& =\mathrm{Rp} 3.626 .416-\mathrm{Rp} 96.398 \\
& =\text { Rp 3.530.018 } \\
& \text { EMV (Santoso) } \quad=(0,71)(\mathrm{Rp} 4.590 .400)+(0,29)(-\mathrm{Rp} 459.040) \\
& =\mathrm{Rp} 3.259 .184-\mathrm{Rp} 133.122 \\
& =\mathrm{Rp} 3.126 .062
\end{aligned}
$$

Nilai EMV yang digunakan dalam mengisi noda keputusan setelah noda cabang adalah: untuk Angkutan Sendiri menggunakan EMV mobil sendiri, yaitu sebesar Rp 3.072.311,-. Sedangkan untuk Jasa Angkutan Paket menggunakan EMV Sinar Aji, yang bernilai paling rendah jika dibandingkan dengan EMV Cito Express, EMV Dakota, EMV Kobra, dan EMV Santoso; yaitu dengan EMV Sinar Aji sebesar Rp 2.563.859,--

Langkah terakhir dalam menentukan titik keputusan yang dapat diambil oleh perusahaan adalah dengan memilih cabang dari hasil EMV terendah yang sebelumnya telah diperoleh untuk jasa angkutan paket dan angkutan sendiri. Pilihan keputusan jatuh pada jasa angkutan Sinar Aji, karena memberikan nilai harapan moneter terendah (EMV terendah) (Gambar 3).

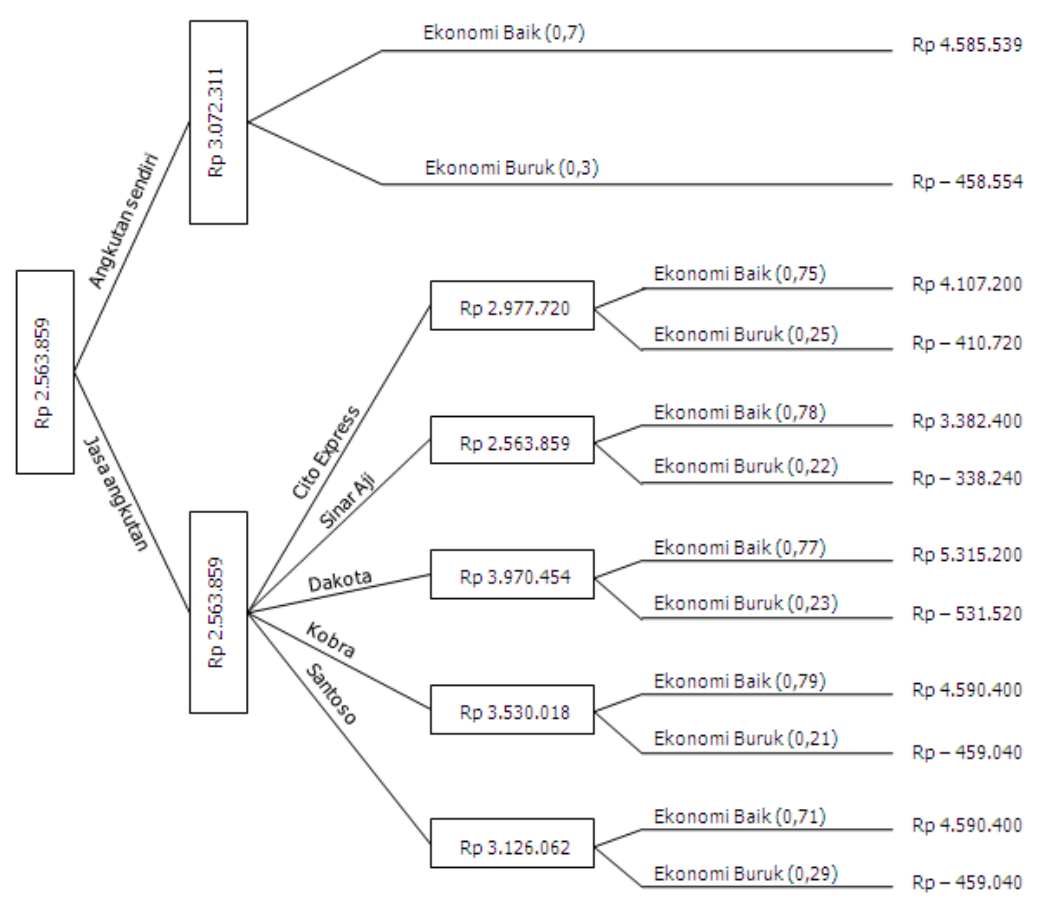

Gambar 3. Diagram pohon untuk menentukan metode pengiriman terbaik tujuan kota Purwokerto

(Sumber: Hasil pengolahan data, 2010). 
Tabel 6 Data Peluang dan Nilai Hasil Keputusan untuk Decision Tree Kota Cirebon

\begin{tabular}{llcccc}
\hline \multirow{2}{*}{ No } & Keterangan & \multicolumn{2}{c}{ Peluang Bagi Kondisi Alamiah } & \multicolumn{2}{c}{ Nilai Hasil Keputusan (Rp) } \\
\cline { 3 - 6 } & & Ekonomi Baik & Ekonomi Buruk & Ekonomi Baik & Ekonomi Buruk \\
\hline & & & & & \\
1. & Mobil Sendiri & 0,7 & 0,3 & \\
& & & & & \\
1. & Cito Express & 0,75 & 0,25 & 3.968 .000 & $(457.925)$ \\
2. & Sinar Aji & 0,78 & 0,22 & 3.224 .000 & $(396.800)$ \\
3. & Dakota & 0,77 & 0,23 & 4.464 .000 & $(446.400)$ \\
4. & Kobra & 0,79 & 0,21 & 4.464 .000 & $(446.400)$ \\
5. & Santoso & 0,71 & 0,29 & 4.216 .000 & $(421.600)$ \\
\hline
\end{tabular}

Sumber: Data dari Perusahaan (2010)

Ekonomi buruk didapat dengan asumsi terjadi kenaikan biaya sebesar $10 \%$ dari harga ekonomi baik.

Untuk pengiriman dengan angkutan sendiri:

$$
\begin{aligned}
\text { EMV (mobil sendiri) } & =(0,7)(\mathrm{Rp} 4.579 .247)+(0,3)(-\mathrm{Rp} 457.925) \\
& =\mathrm{Rp} 3.205 .473-\mathrm{Rp} 137.378 \\
& =\mathrm{Rp} 3.068 .095
\end{aligned}
$$

Untuk pengiriman dengan jasa angkutan paket:

$$
\begin{aligned}
& \text { EMV (Cito Express) } \quad=(0,75)(\mathrm{Rp} 3.968 .000)+(0,25)(-\mathrm{Rp} 396.800) \\
& =\mathrm{Rp} 2.976 .000-\mathrm{Rp} 99.200 \\
& =\operatorname{Rp} 2.876 .800 \\
& \operatorname{EMV~(Sinar~Aji)~} \quad=(0,78)(\mathrm{Rp} 3.224 .000)+(0,22)(-\mathrm{Rp} 322.400) \\
& =\operatorname{Rp} 2.514 .720-\mathrm{Rp} 70.928 \\
& =\operatorname{Rp} 2.443 .792 \\
& \operatorname{EMV~(Dakota)~} \quad=(0,77)(\mathrm{Rp} 4.464 .000)+(0,23)(-\mathrm{Rp} 446.400) \\
& =\mathrm{Rp} 3.437 .280-\mathrm{Rp} 102.672 \\
& =\mathrm{Rp} 3.334 .608 \\
& \operatorname{EMV~(Kobra)~} \quad=(0,79)(\mathrm{Rp} 4.464 .000)+(0,21)(-\mathrm{Rp} 446.400) \\
& =\mathrm{Rp} 3.526 .560-\mathrm{Rp} 93.744 \\
& =\operatorname{Rp} 3.432 .816 \\
& \text { EMV (Santoso) } \quad=(0,71)(\mathrm{Rp} 4.216 .000)+(0,29)(-\mathrm{Rp} 421.600) \\
& =\mathrm{Rp} 2.993 .360-\mathrm{Rp} 122.264 \\
& =\operatorname{Rp} 2.871 .096
\end{aligned}
$$

Nilai EMV yang digunakan dalam mengisi noda keputusan setelah noda cabang adalah: untuk Angkutan Sendiri menggunakan EMV mobil sendiri, yaitu sebesar Rp 3.068.095,-. Sedangkan untuk Jasa Angkutan Paket menggunakan EMV Sinar Aji, yang bernilai paling rendah jika dibandingkan dengan EMV Cito Express, EMV Dakota, EMV Kobra, dan EMV Santoso; yaitu dengan EMV Sinar Aji sebesar Rp 2.443.792,-.

Langkah terakhir dalam menentukan titik keputusan yang dapat diambil oleh perusahaan adalah dengan memilih cabang dari hasil EMV terendah yang sebelumnya telah diperoleh untuk jasa angkutan paket dan angkutan sendiri. Pilihan keputusan jatuh pada jasa angkutan Sinar Aji, karena memberikan nilai harapan moneter terendah (EMV terendah) (Gambar 4). 


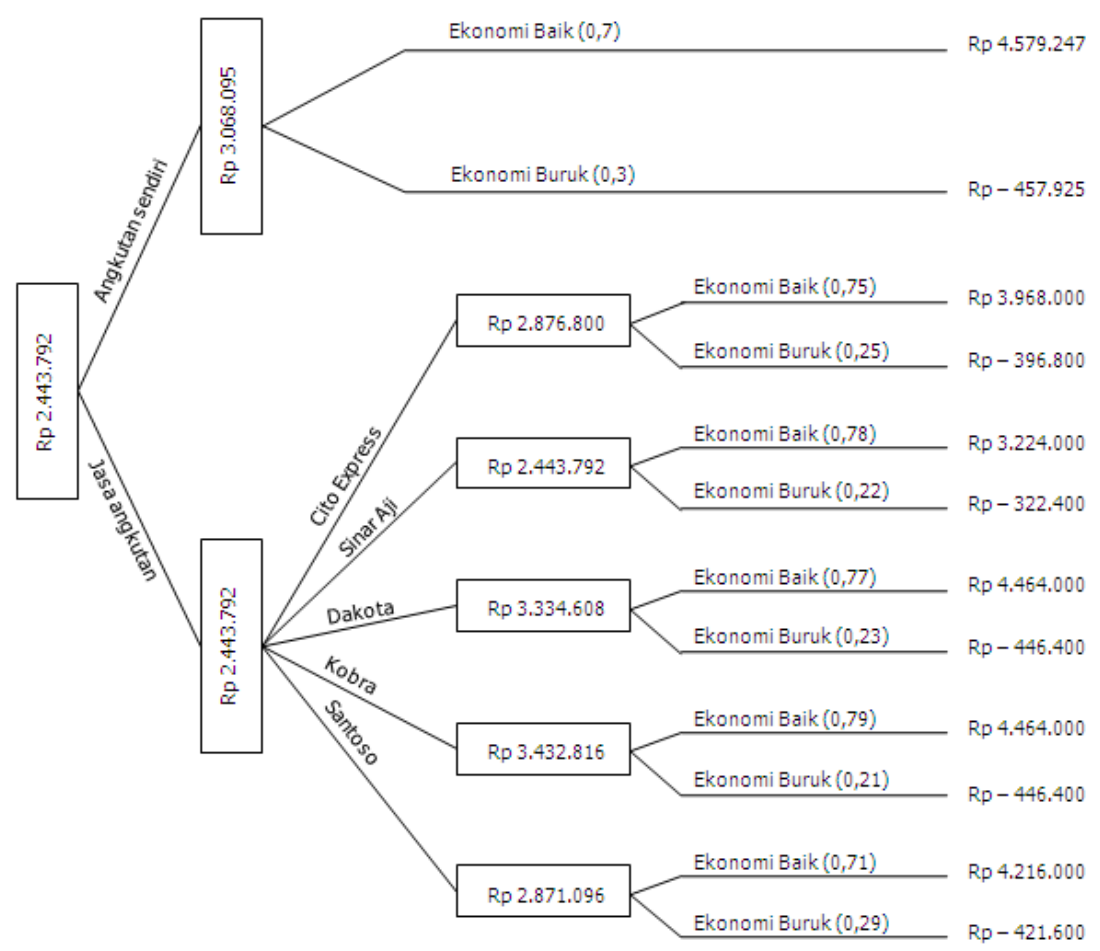

Gambar 4. Diagram pohon untuk menentukan metode pengiriman terbaik tujuan kota Cirebon (Sumber: Hasil Pengolahan Data, 2010).

Tabel 7 Data Peluang dan Nilai Hasil Keputusan untuk Decision Tree Kota Semarang

\begin{tabular}{llcccc}
\hline \multirow{2}{*}{ No } & Keterangan & \multicolumn{2}{c}{ Peluang Bagi Kondisi Alamiah } & \multicolumn{2}{c}{ Nilai Hasil Keputusan (Rp) } \\
\cline { 3 - 6 } & & Ekonomi Baik & Ekonomi Buruk & Ekonomi Baik & Ekonomi Buruk \\
\hline & & & & & \\
1. & Mobil Sendiri & 0,7 & 0,3 & 6.777 .887 & $(677.789)$ \\
& & & & & \\
1. & Cito Express & 0,75 & 0,25 & 7.209 .150 & $(720.915)$ \\
2. & Sinar Aji & 0,78 & 0,22 & 5.545 .500 & $(554.550)$ \\
3. & Dakota & 0,77 & 0,23 & 8.872 .800 & $(887.280)$ \\
4. & Kobra & 0,79 & 0,21 & 8.318 .250 & $(831.825)$ \\
5. & Santoso & 0,71 & 0,29 & 7.763 .700 & $(776.370)$ \\
\hline
\end{tabular}

Sumber: Data dari Perusahaan (2010)

Ekonomi buruk didapat dengan asumsi terjadi kenaikan biaya sebesar $10 \%$ dari harga ekonomi baik.

Untuk pengiriman dengan angkutan sendiri:

EMV (mobil sendiri) $\quad=(0,7)(\mathrm{Rp} 6.777 .887)+(0,3)(-\mathrm{Rp} 677.789)$

$=\mathrm{Rp} 4.744 .521-\mathrm{Rp} 203.337$

$=$ Rp 4.541.184

Untuk pengiriman dengan jasa angkutan paket:

EMV (Cito Express) $\quad=(0,75)($ Rp 7.209.150) $+(0,25)(-$ Rp 720.915)

$=\mathrm{Rp} 5.406 .863-\mathrm{Rp} 180.229$

$=\mathrm{Rp}$ 5.226.634 
EMV (Dakota)

$$
\begin{aligned}
& =(0,77)(\mathrm{Rp} 8.872 .800)+(0,23)(-\mathrm{Rp} 887.280) \\
& =\mathrm{Rp} 6.832 .056-\mathrm{Rp} 204.074
\end{aligned}
$$$$
=\operatorname{Rp} 6.627 .982
$$

EMV (Kobra)

$=(0,79)(\mathrm{Rp} 8.318 .250)+(0,21)(-\mathrm{Rp} 831.825)$

$=\mathrm{Rp} 6.571 .418-\mathrm{Rp} 174.683$

$=$ Rp 6.396.735

EMV (Santoso)

$$
\begin{aligned}
& =(0,71)(\mathrm{Rp} 7.763 .700)+(0,29)(-\mathrm{Rp} 776.370) \\
& =\mathrm{Rp} 5.512 .227-\mathrm{Rp} 225.147 \\
& =\mathrm{Rp} 5.287 .080
\end{aligned}
$$

Nilai EMV yang digunakan dalam mengisi noda keputusan setelah noda cabang adalah: untuk Angkutan Sendiri menggunakan EMV mobil sendiri, yaitu sebesar Rp 4.541.184,-. Sedangkan untuk Jasa Angkutan Paket menggunakan EMV Sinar Aji, yang bernilai paling rendah jika dibandingkan dengan EMV Cito Express, EMV Dakota, EMV Kobra, dan EMV Santoso; yaitu dengan EMV Sinar Aji sebesar Rp 4.203.489,--

Langkah terakhir dalam menentukan titik keputusan yang dapat diambil oleh perusahaan adalah dengan memilih cabang dari hasil EMV terendah yang sebelumnya telah diperoleh untuk jasa angkutan paket dan angkutan sendiri. Pilihan keputusan jatuh pada jasa angkutan Sinar Aji, karena memberikan nilai harapan moneter terendah (EMV terendah) (Gambar 5).

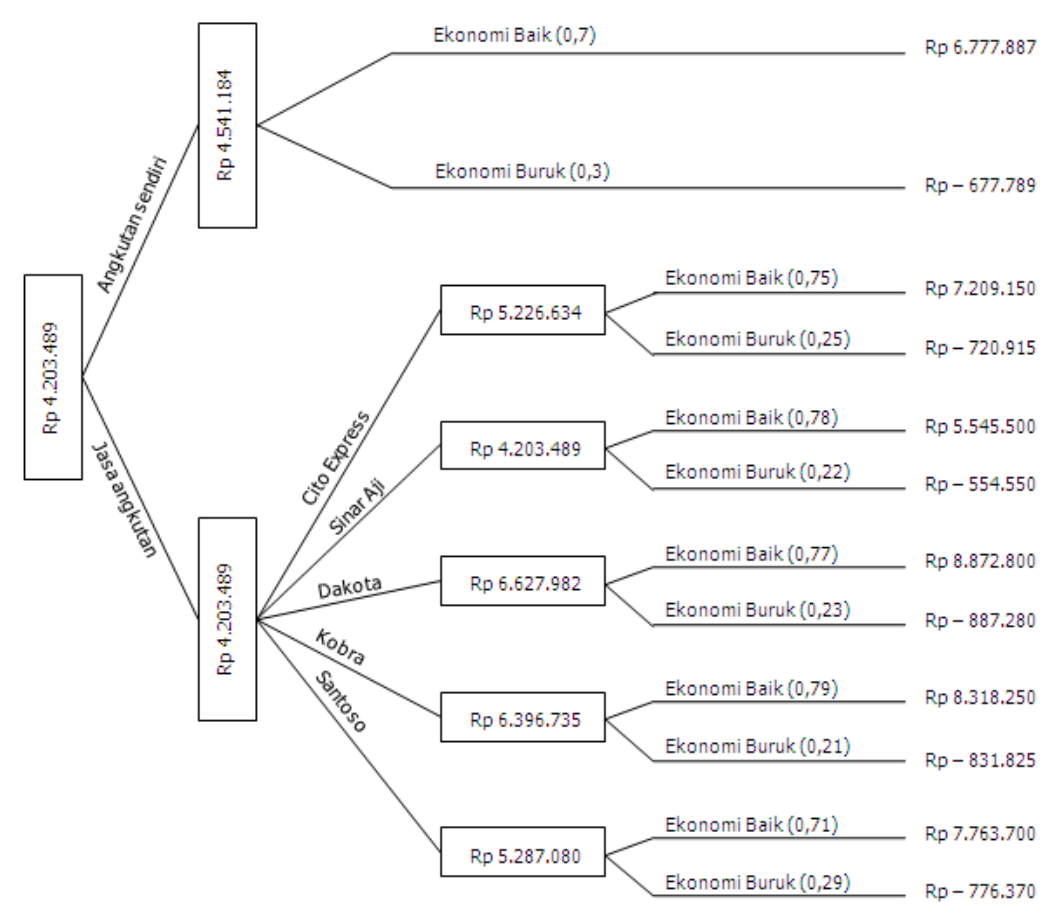

Gambar 5. Diagram pohon untuk menentukan metode pengiriman terbaik tujuan kota Semarang (Sumber: Data Hasil Pengolahan, 2010). 


\section{PENUTUP}

Berdasarkan analisis dan hasil perhitungan yang telah diperoleh, dapat diambil kesimpulan terhadap pelaksanaan pengiriman barang pada PT. Suryamas Inti Armindo sebagai berikut: (1) biaya optimal pengiriman barang PT. Suryamas Inti Armindo dengan menggunakan jasa angkutan paket menurut metode NWC, Least Cost, dan VAM adalah sebesar Rp 25.849.450,-- serta biaya pengiriman dengan metode yang sedang berjalan adalah sebesar Rp 24.715.192,-; (2) berdasarkan biaya pengiriman barang yang diperoleh di atas, metode pengiriman barang yang sebaiknya digunakan oleh PT. Suryamas Inti Armindo yaitu metode yang sedang berjalan; (3) dalam mengoptimalkan efisiensi biaya pengiriman barang dengan menggunakan pendekatan decision tree, solusi yang sebaiknya dipilih oleh PT. Suryamas Inti Armindo yaitu: untuk kota Yogyakarta menggunakan jasa angkutan paket Sinar Aji, untuk kota Salatiga menggunakan jasa angkutan mobil sendiri, untuk kota Purwokerto menggunakan jasa angkutan paket Sinar Aji, untuk kota Cirebon menggunakan jasa angkutan paket Sinar Aji, dan untuk kota Semarang menggunakan jasa angkutan paket Sinar Aji.

\section{DAFTAR PUSTAKA}

Heizer, Jay dan Render, Barry. (2005). Manajemen Operasi (edisi ketujuh). Jakarta: Salemba Empat.

Horngren, Charles T. dan Foster, George. (2004). Akuntansi Biaya Suatu Pendekatan Manajerial (jilid I, edisi kesembilan). Jakarta: Erlangga.

Kotler, Philip. (2003). Marketing Management (eleventh edition). New Jersey: Prentice Hall.

Maher, Michael W dan Deakin, Edward B. (2001). Akuntansi Biaya (jilid I, edisi keenam). Jakarta: Erlangga.

Matz, Adolph dan Usry, Milton F. (2002). Akuntansi Biaya Perencanaan dan Pengendalian, (jilid I, edisi kesebelas). Jakarta: Erlangga.

Mulyono, Sri. (2004). Riset Operasi (edisi revisi). Jakarta: Lembaga Penerbit Fakultas Ekonomi Universitas Indonesia.

Render, Barry dan Hanna, Michael E. (2006). Quantitative Analysis for Management. New Jersey: Prentice Hall.

Robbins, Stephen P. dan Coulter, Mary. (2009). Manajemen (edisi kedelapan). Jakarta: Salemba Empat.

Sarjono, Haryadi. (2010). Aplikasi Riset Operasi. Jakarta: Salemba Empat.

Siswanto. (2006). Operations Research (jilid 2). Jakarta: Erlangga.

Stoner, James A. F. (2006). Manajemen (jilid I, edisi keenam). Jakarta: Salemba Empat. 